Article

\title{
Evaluating the Environmental Impacts of Personal Protective Equipment Use by the General Population during the COVID-19 Pandemic: A Case Study of Lombardy (Northern Italy)
}

\author{
Gilberto Binda ${ }^{1, *(\mathbb{D})}$, Arianna Bellasi ${ }^{1}$, Davide Spanu ${ }^{1}$ (D), Andrea Pozzi ${ }^{1}$, Domenico Cavallo ${ }^{1}$ \\ and Roberta Bettinetti $2, * \mathbb{D}$
}

Citation: Binda, G.; Bellasi, A.; Spanu, D.; Pozzi, A.; Cavallo, D.; Bettinetti, R. Evaluating the Environmental Impacts of Personal Protective Equipment Use by the General Population during the COVID-19 Pandemic: A Case Study of Lombardy (Northern Italy).

Environments 2021, 8, 33 .

https://doi.org/10.3390/

environments 8040033

Academic Editor: Hynek Roubík

Received: 2 March 2021

Accepted: 13 April 2021

Published: 15 April 2021

Publisher's Note: MDPI stays neutral with regard to jurisdictional claims in published maps and institutional affiliations.

Copyright: (c) 2021 by the authors. Licensee MDPI, Basel, Switzerland. This article is an open access article distributed under the terms and conditions of the Creative Commons Attribution (CC BY) license (https:// creativecommons.org/licenses/by/ $4.0 /$ )
1 Department of Science and High Technology, University of Insubria, Via Valleggio 11, 22100 Como, Italy; abellasi@uninsubria.it (A.B.); d.spanu1@uninsubria.it (D.S.); andrea.pozzi@uninsubria.it (A.P.); domenico.cavallo@uninsubria.it (D.C.)

2 Department of Human Science of the Innovation for the Territory, University of Insubria, Via Valleggio 11, 22100 Como, Italy

* Correspondence: gilberto.binda@uninsubria.it (G.B.); roberta.bettinetti@uninsubria.it (R.B.)
Abstract: The diffusion of Coronavirus disease (COVID-19) impacted the whole world, changing the life habits of billions of people. These changes caused an abundant increase in personal protective equipment (PPE, e.g., masks and gloves) use by the general population, which can become a concerning issue of plastic pollution. This study aims to evaluate the negative effects of the abundant PPE use following the COVID-19 diffusion using the test site of the Lombardy region, an area highly affected by the pandemic. Population data were retrieved from national databases, and the COVID-19 national guidelines were considered to estimate the total use of PPEs during 2020. Then, the quantity of waste derived from their use was evaluated based on the weight of PPEs. As well, possible scenarios for 2021 were proposed based on 2020 estimations. The results suggested different negative effects of the diffusion of PPEs both on waste management and on the environment: The abundant increase in PPEs-derived waste caused an increase in terms of costs for management, and the potential direct spreading in the environment of these materials (especially masks) poses a serious threat for an increase in microplastics in water bodies. Following this evaluation, a careful choice regarding COVID-19 measures of containment should be performed especially by the general population, avoiding contagion diffusion and reducing the possible environmental impact derived from disposable PPE use.

Keywords: COVID-19; personal protective equipment; environmental risk; plastic; waste management

\section{Introduction}

The pandemic diffusion of Severe Acute Respiratory Syndrome Coronavirus 2 (SARSCov II) pneumonia disease (COVID-19) [1] highly affected the life of the human population worldwide, causing severe sanitary emergencies, as well as more than 1,900,000 fatalities worldwide in 2020, posing a serious threat for the national sanitary systems in different countries [2]. Emergency measures of social distancing to minimize the diffusion of the disease were adopted worldwide (with different time spans after the outbreak). These measures include the adoption of remote working and learning, the addition of strict hygiene rules for the exposed population, and the use of personal protective equipment (PPE), such as disposable masks and gloves [3].

The priority of research and risk management was inevitably focused on human health, considering the severity of COVID-19 effects on human beings. Nonetheless, the pandemic diffusion of COVID-19 and the consequent changes in life habits of the whole human population altered the recent human impact on the environment worldwide, revealing 
both positive and negative consequences [4-6]. Among the positive effects observed so far, a mitigation of $\mathrm{CO}, \mathrm{O}_{3}, \mathrm{NO}_{\mathrm{x}}$, and $\mathrm{PM}_{2.5}$ (and to a lesser extent $\mathrm{PM}_{10}$ ) human impact on the atmosphere, as well as a reduction in anthropogenic noise was observed in different urban settings, following the reduction in vehicular traffic [7-11]; basin water quality was observed to improve during the COVID-19 lockdown as well [12].

On the other hand, the severe risk of negative environmental impacts regarding the COVID-19 pandemic has just recently been taken into account by the scientific community: The great increase in plastic use considering the enormous increase in production and demand for personal protective equipment [13-15], can turn into a great problem for waste management [5,15-18]. For example, the World Health Organization (WHO) during the first months of 2020 requested a $40 \%$ increase in disposable PPE production [19]. In this context, a great number of PPEs were increasingly used in the healthcare system [13]. The use of these materials exponentially increased in the general population too, raising potential threats for the management of plastic wastes. The waste management of sanitary and hazardous material is highly monitored, while the evaluation of environmental impacts of mismanaged urban waste can be more complicated.

Most disposable face masks are made of nonwoven materials (e.g., spunbond and meltblown spunbond), often incorporating polypropylene and polyethylene $[17,20]$. Gloves are made of different plastic materials (Low-Density Polyethylene, nitrile, latex, vinyl), presenting strong mechanic and chemical resistance, causing high persistence in the environment after possible dispersion [21-23]. Similar to other plastic waste, PPE-derived waste that is not properly treated can be spread into the environment and will probably reach water bodies as the final sink [24].

This study aims to quantify the role of the general population on plastic pollution by the abundant use of PPEs, based on a case study of the Lombardy region (Figure 1a). This area in northern Italy represents a unique case study: It was among the first hot-spot areas of COVID-19, contains the second biggest city in the country (Milan) with different urbanized areas, which were affected by a heavy change in life habits connected with COVID-19 diffusion and presents a long time series of PPE use after the first outbreak, due to the emergency measures imposed to reduce the virus spread [25]. In contrast to other studies, which so far have been mainly focused on life cycle assessment of plastic waste derived from hospitals $[13,26]$, our aim is to investigate the role of the general population in the COVID19 related plastic pollution issue, understanding if a more conscious and environmentally friendly behavior for contagion reduction can possibly reduce the environmental impact (in terms of plastic waste increase and dispersion into the environment), maintaining good protection from the contagion.

The estimation of possible environmental impacts connected with waste material derived from the use of PPEs by the general population in this site can warn about the severe environmental threats in other settings. An irresponsible management of this emerging class of wastes could be in fact a potential environmental issue in the near future, considering that COVID-19 diffusion (especially in Europe) is continuously increasing.

\section{Materials and Methods}

\subsection{Study Area: Epidemiological Situation and Social Implications}

Italy has been severely and rapidly impacted by the COVID-19 diffusion [27], with more than 70,000 fatalities in 2020, reaching a fatality rate of 7.2\% among the infected [28]. The Lombardy region (Figure 1a), in more detail, is among the most affected areas, presenting a hot-spot in contagions, with a total of 195,000 infected, updated to 1 November 2020 [29-31].

The health emergency in the area was managed with different phases related to the epidemiological development of the COVID-19 outbreak (see Figure 1b).

Phase 1: A lockdown period (from 9 March 2020 to 18 May 2020) when most nonnecessary businesses were closed [25]. Social distancing, smart working, and home learning for school students, as well as the use of PPE and sanitizing solutions, were suggested 
for the general population in order to reduce the spread of the virus. Masks were considered mandatory on public transport and in every indoor environment. Only the retail trade for food and the industry connected with the production chain were kept open, while food services were strictly limited, permitting takeaway only and delivery services. It was estimated that $48.3 \%$ of the businesses had to shut down during this period in Lombardy [32].

(a)
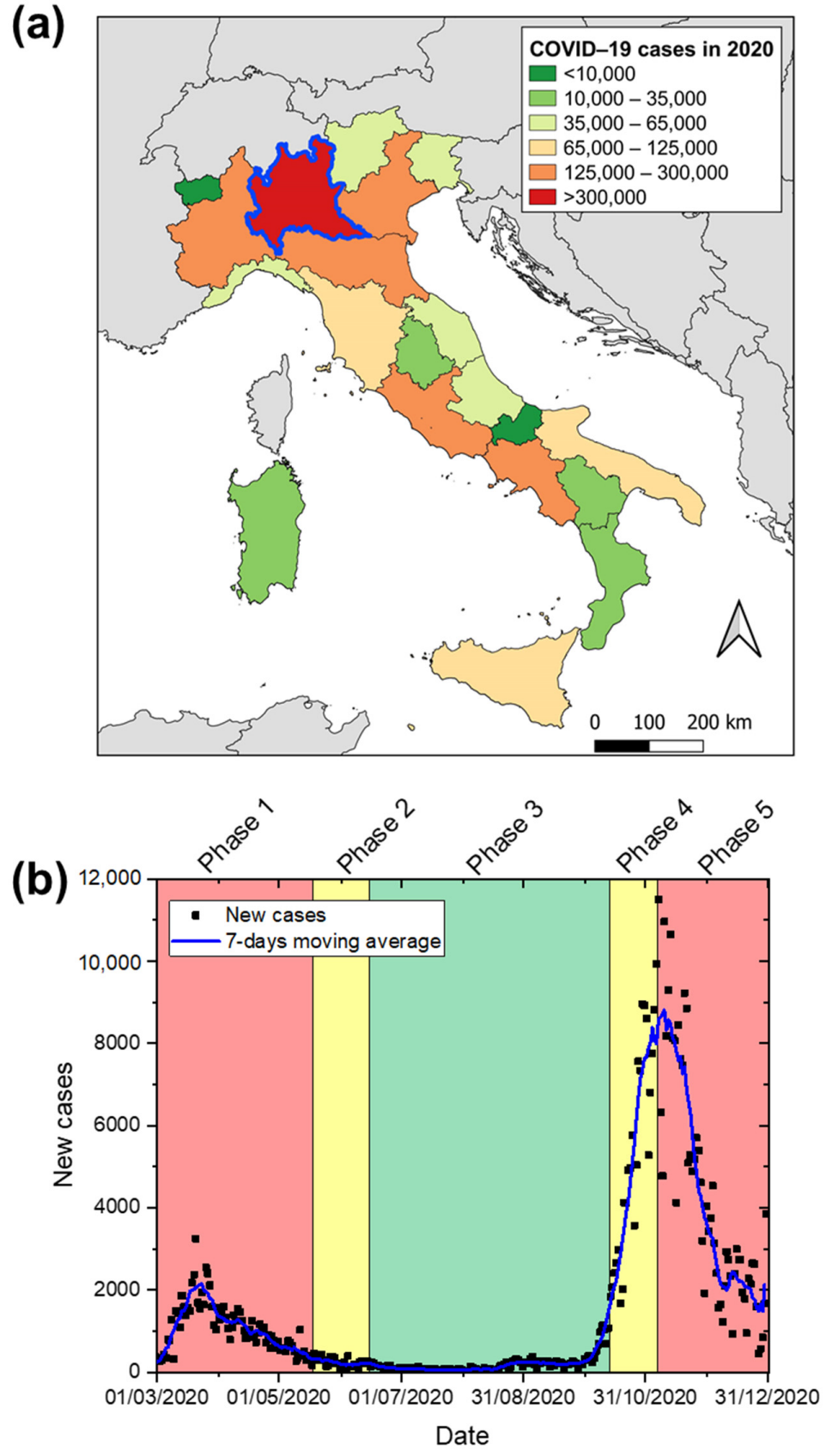

Figure 1. (a) Total number of COVID-19 contagions in the different regions of Italy in 2020, the study area of Lombardy is highlighted with blue boundaries. (b) Number of daily new cases in Lombardy (black symbols) and 7-day moving average (blue line) in the different phases (epidemiological data obtained from [33]). The background is colored differently depending on the different limitations in the distinct phases of pandemic control policies (green for period permitting mobility, yellow for limited mobility periods and red for high restrictions and lockdown periods). 
Phase 2: Following a reduction in new cases and good management of hospital healthcare, first non-necessary businesses were opened starting from 18 May, including all shops and retailers, restaurants and food services, hotels, sports plants (swimming pools and gyms) with some restriction on maximum occupancy in order to maintain a minimum distance of $1 \mathrm{~m}$ among commuters. Moreover, transport limitations for the general population were removed, and people could start to move from houses to visit relatives and practice outdoor activities. The use of protective equipment remained mandatory in indoor environments.

Phase 3: From 15 June, other social businesses (bingos, SPAs, thermal plants, kindergartens) started their activity again. As well, concerts, theatres, cinemas reopened with strict restrictions regarding maximum occupancy. On the other hand, other businesses, such as ballrooms and dance clubs, were kept closed. Moreover, on 14 September, students of all grades started normal scholastic activity at schools.

Phase 4: The limited restrictions were kept until 13 October, with the new number of cases increasing, possibly related to the climate of the study area [34]. In this period, some restrictions were reintroduced, including limited use of food services and the closure of cinemas, theatres and other social activities.

Phase 5: Finally, a new lockdown period was announced starting from 6 November in Lombardy and lasting for at least one month. In this case, in contrast to the 1st phase, schools remained open until the sixth grade, while most food services (restaurants and bars) had to shut down. Industries could stay open. As well, social distancing measures were reintroduced for the general population limiting mobility for non-necessary operations. Similar measures, limited mobility, and social distancing were maintained until the beginning of 2021.

\subsection{Population Data and Assumptions for PPE Use}

The abovementioned health and social situation caused an increase in the use of PPEs without precedence in the study area: The use of this kind of equipment was mainly limited to health workers prior to the COVID-19 outbreak. Therefore, in this section, we will describe the parameters and data sources used to estimate this unique increase in PPE use in Lombardy. To evaluate the likely number of disposable PPEs that were used by workers, the indications of the Istituto Superiore di Sanità (ISS) and the Italian Ministry of Labor have been considered [35,36], applying different utilization rates depending on the businesses category. While, for the general population, different behaviors have been considered for the abovementioned phases depending on the age classes of the population.

\subsubsection{Retrieved Databases}

All the data based on population statistics in the region selected for the study and used to develop the scenarios (including number of inhabitants, families, number of businesses, and population habits) were retrieved from online sources of regional and national governmental databases [32,37-40]. These databases are under open data license. Population data retrieved and the references of original data sources are available in Supplementary Material, Table S1.

All the data were then computed using Microsoft Excel spreadsheets, preparing sums, numbers of people, and consequent PPE use in the different phases of 2020, as well as in the future scenarios for 2021.

\subsubsection{General Population}

The population in Lombardy is of about 10 million people, with about 4.5 million families (the average number of family members is 2.2). The population distribution for age is reported in Figure 2, indicating close to $50 \%$ in sex ratio and the more abundant class of population aged between 41 and 50 years. This age class is the most active population, which moves for work and family reasons (see Table 1). 


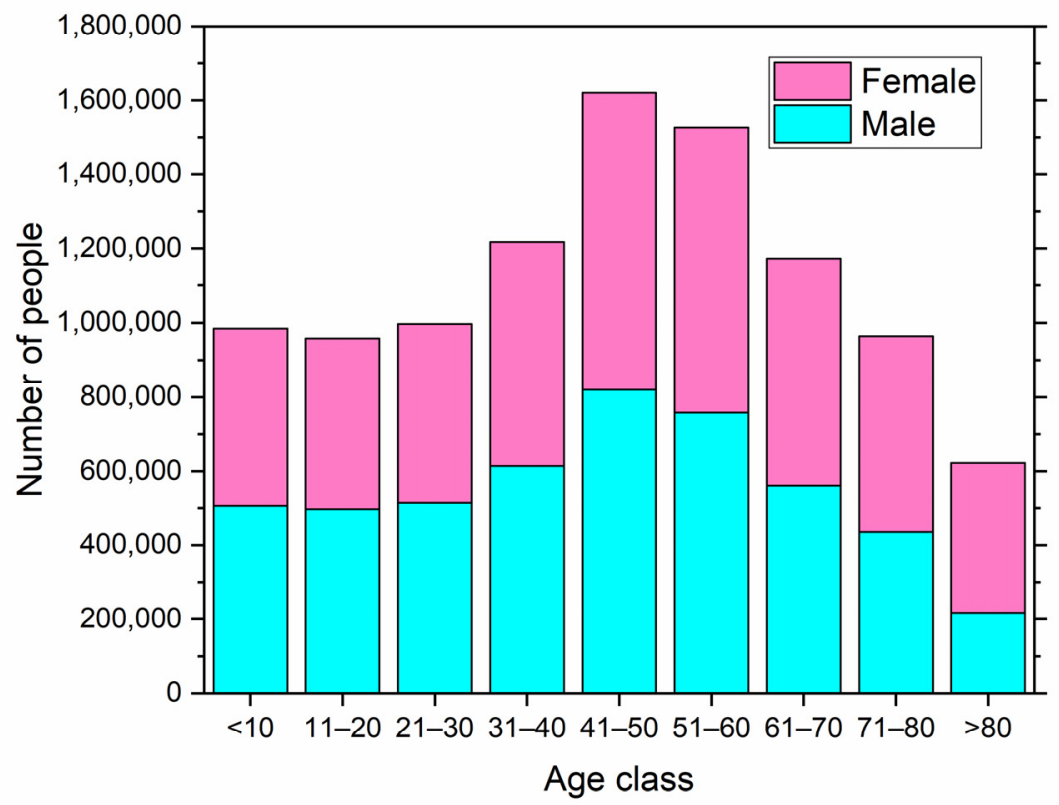

Figure 2. Age classes and sex ratio of the population in the Lombardy region.

Table 1. Normal mobility rate for the different age classes in Italy and changes observed during the lockdown phases [41]. People belonging to the different age classes are also reported.

\begin{tabular}{ccccc}
\hline Class of Age (Years) & $\begin{array}{c}\text { Mobility Rate in } \\
\mathbf{2 0 1 9}(\mathbf{\%})\end{array}$ & $\begin{array}{c}\text { Mobility Rate during } \\
\text { the Phase 1 (\%) }\end{array}$ & $\begin{array}{c}\text { Assumed Mobility in } \\
\text { Phases 2, 4 and 5 (\%) }\end{array}$ & $\begin{array}{c}\text { Number of People in } \\
\text { Lombardy }\end{array}$ \\
\hline $14-29$ & 91 & 57 & 74 & $1,551,026$ \\
$30-45$ & 94 & 66 & 80 & $2,112,238$ \\
$46-64$ & 92 & 66 & 59 & $2,847,495$ \\
$65-80$ & 72 & 30 & 51 & $1,650,392$ \\
\hline
\end{tabular}

Among young people, there are a total of about 1.5 million students (ranging from kindergarten to high school). It should also be considered that following current safety rules, kids younger than 6-year-old can avoid using PPEs [25]. Data on PPE use by the general population were assumed in the different phases depending on age, basing on the different mobility habits of Italians. Mobility of different age classes was, therefore, considered as in Table 1 for phase 1 , then considered as normal habits in phase 3 . For the other phases, since there was no direct data available, an average mobility rate between phases 1 and 3 was considered.

Considering the different periods for limitation in movements, the use of PPEs by the general population included an average of 1 mask a day when going out (considering the people using reusable masks and people using more than one mask a day) and 1 pair of gloves. Gloves were considered as being used by the general population only until the end of the 2nd phase. In fact, by the second half of March, the use of gloves in Italy reduced significantly after new guidelines for the general population were introduced, and by phase 3, gloves were not recommended by the Italian regulations [25]. Maintenance of hand hygiene through sanitizer and abundant washing was instead suggested.

\subsubsection{Industrial Sector}

The industrial sector in Lombardy includes about 1,408,000 workers [32]. Nearly half $(45 \%)$ of the industries had to shut down in the 1st phase, while industries directly related to necessary goods were kept open [42]. Then, in the following phases, industries could continue their activities, following safety protocols [43].

Assumptions included the use of 1 mask per person per day and 1 pair of gloves per person per day until the $3 \mathrm{rd}$ phase for the reasons already explained in the previous paragraph. 


\subsubsection{Retail Trade}

Our data collection involved all activities in the sector of retail trade. The type of businesses of retail trading was divided according to food traders and other good traders. The food traders were considered essential businesses (which worked in all phases), while other nonessential goods traders were deemed to be open in the 2nd and 3rd phases. A total of 242,640 workers are included in the retail trade in Lombardy; about $60 \%(147,373)$ work in the retail of other goods. The estimated use of gloves included 1 pair a day per person until the beginning of the 3rd phase, while the average use of 1 mask for each employee a day was considered, following restrictions rules for hygiene [43]. In contrast, a pair of gloves per day was considered for the whole period for people working with food products.

\subsubsection{Food Businesses}

In Lombardy, there are 51,016 businesses for food services, which generally involve 918,100 employed people. Nonetheless, this sector was among the most affected by the COVID-19 situation, with a decrease of about 30\% in the employment rate [44]. Workers in this sector had to maintain the use of gloves for sanitary reasons (two pairs of gloves per person were estimated during a workday) and had to use face masks ( 1 per day was estimated).

In normal conditions, the average consumption habits in restaurants in Italy include 3 meals out per person per week [40]. Nonetheless, the crisis of this sector and the changes in habits after the lockdown negatively affected the total amount of guests in this business sector. Consequently, a change in the citizen habits, with the reduction in the number of meals in restaurants, considering the guidelines of distancing [36], caused a severe reduction in costumers for the tourism sector (and consequently restaurants), estimated to be $30 \%$ compared to 2019 data [44]. Moreover, it should be considered that during the 3rd phase, restaurants could also welcome guests, while in other phases, they could only deliver food or work with a takeaway service. Therefore, the number of masks used by guests was considered as $70 \%$ of the normal number of people only during the $3 \mathrm{rd}$ phase, considering that people moving for deliveries were already counted for the general population mobility.

\subsubsection{Services}

The total number of workers in the sector of services is of about 3 million people [32]. During the pandemic, different sectors of personal services (including administration, logistics, finance) pushed highly for smart working, especially during the 1st phase, during which about $65 \%$ of the workers had to work remotely [32]. Only following this period, depending on the different needs of the societies, workers moved to the office or continued working from home. Since for other phases direct data were not available, an average situation between pre-COVID19 and 1st phase was assumed, with $32.5 \%$ of workers in smart working. When working in offices, the same conditions as other workers were considered regarding the use of PPEs (see Section 2.2.3, Industrial Sector).

\subsection{Other Assumptions for PPE Use Estimation and Waste Management}

For the comprehensive estimation of PPE use by the general population, other general estimations from population data were considered.

First, while sectors were impacted differently, an average reduction in work occupancy by $17 \%$ was evaluated from 2019 to 2020 in Italy [45]. Therefore, in sectors where direct data on business reduction were not available, this value was applied during the pandemic phases.

Moreover, healthcare businesses (e.g., hospitals and dental clinics) were not considered in this study, since the use of PPEs by health workers is inevitable, workers in this industry are well instructed regarding the correct use of this kind of equipment, and the wastes of sanitary structures undergoes a specific waste recovery system for hazardous materials. 


\section{Results}

In this section, following the proposed scenario and different activities selected in the Methods section, the quantity of used (and then potentially dispersed into the environment) PPEs during 2020 in Italy will be estimated. Then, the potential impact on plastic waste derived from PPE in the future period will be forecast for 2021. In order to quantitively understand the overall potential impacts of the anomalous increase in the use of PPEs by the general population and to understand the possible negative effects on the waste management system (as well as the direct effects on the environment), the impact on different scenarios was calculated as the total amount of waste produced weekly by the different population and production sectors [46].

Firstly, the weight of PPE materials needs to be considered in order to evaluate their impacts in quantitative terms (Figure 3). Considering the average weight of a pair of gloves ( $4.14 \mathrm{~g}$, estimated from the different polymers used in the market [47]) and the average weight of face mask (calculated as $9.56 \mathrm{~g}$, basing on the use of both surgical and N95 single use masks [48]), the total amount of used PPEs calculated from population habits will be discussed in the results section in terms of the total weight of waste.

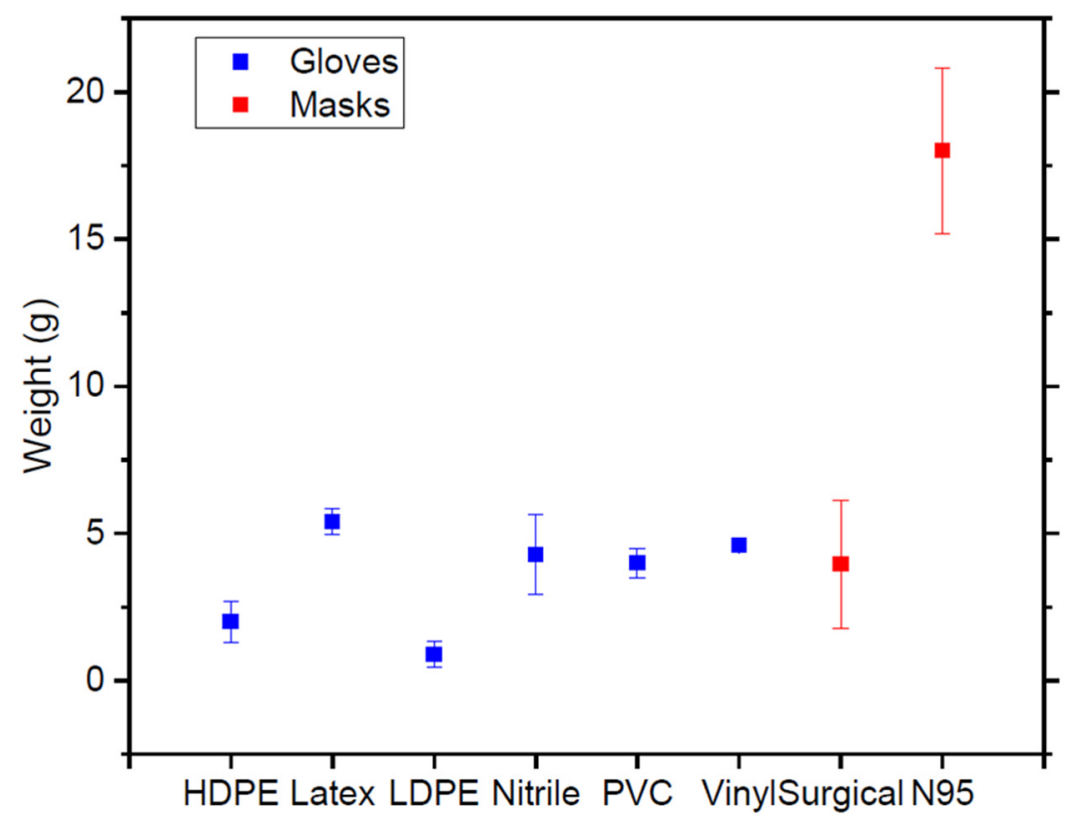

Figure 3. Weight for gloves of every different polymer and masks of different typologies (HDPE: High-Density Polyethylene, LDPE: Low-Density Polyethylene, PVC: Polyvinyl Chloride). Symbols indicate the average value, while bars indicate the standard deviation.

\subsection{Estimation of the Load of Produced and Dispersed PPE Waste during 2020}

Overall, a total amount of 30,823 tons of plastic waste was estimated by the general population and workers in Lombardy for the whole year 2020. Raw calculated data from different population sectors are instead reported in Supplementary Materials, Tables S2 and S3.

Figure 4 shows the potential amount of waste generated weekly in the different phases, divided into masks and gloves. It is observable that generally, the use of PPEs by the general population was inversely correlated with the mobility restrictions since social distancing favors protection without any possible negative impact on the environment. It is clear, in fact, that during the 1st phase, the use of masks by the general population was quite limited compared to the following ones. The trend for gloves was highly different since these PPEs were highly consumed in the first period of the pandemic in Italy, but then their use was only suggested for some professional sectors, and the use by the general population was notably reduced. Therefore, considering the overall plastic waste production during 2020 from PPEs, the 2 nd phase resulted in the most impacting. Considering that $2 \%$ of total 
plastic waste was estimated to be PPEs directly dispersed into the environment [49], in this period of maximum production, up to 18 tons of plastic waste could be directly spread into the environment every week.

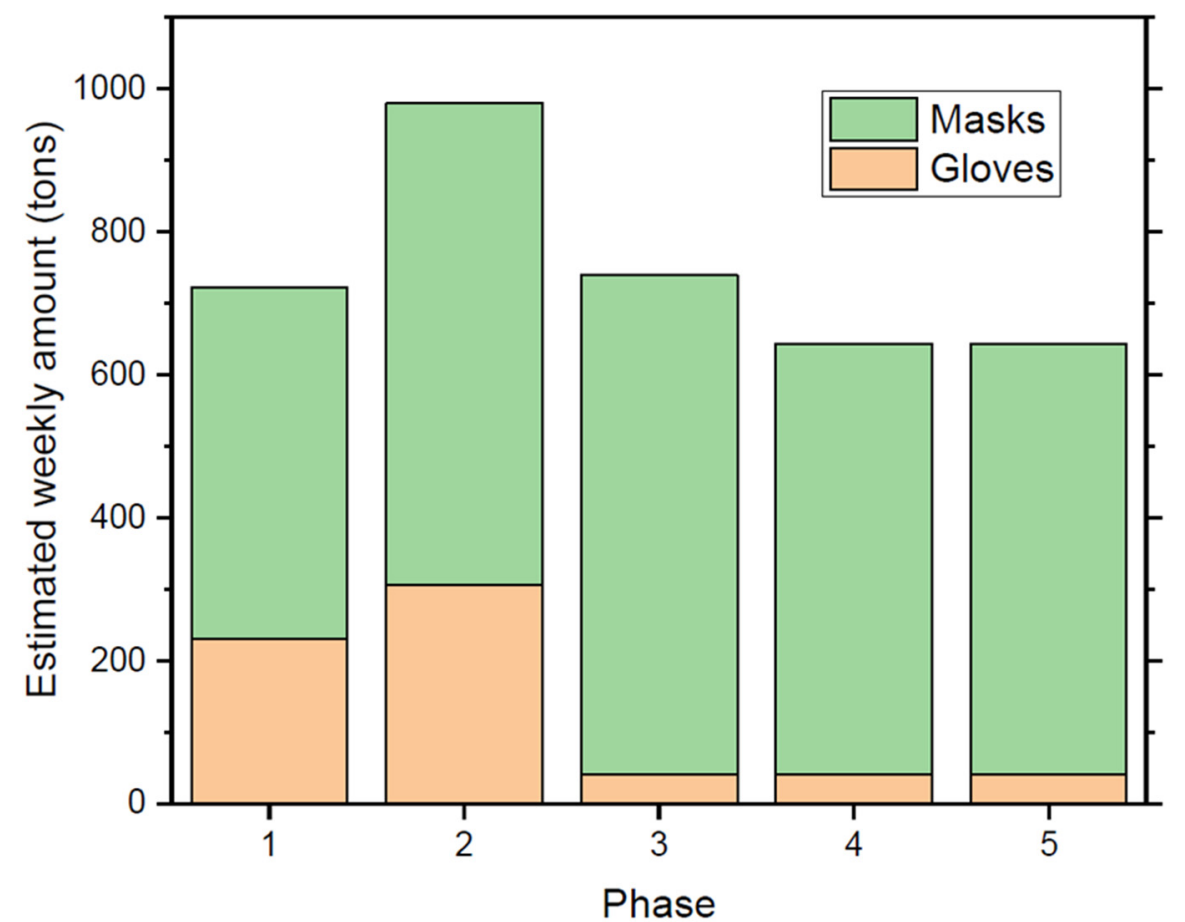

Figure 4. Weekly amount of plastic waste from PPEs in the different phases of COVID-19 management in Lombardy.

Analyzing then the different production rates from all the population categories considered in this study (Figure 5), an important role was notable from the mobility of the general population. In fact, the amount of waste from PPEs used by the general population was more than all the other categories, analyzing the average production of all phases for masks (and in phases 1 and 2 for gloves, the period of maximum use).

It is also notable that, in the field of services, while a high percentage of workers used other strategies to avoid contagion (e.g., smart working), the high number of workers in this sector in Lombardy caused a relatively high impact. Observing the food sector, instead, the more abundant use of gloves derived from the safety regulations caused different impacts for the different PPEs in this sector. 

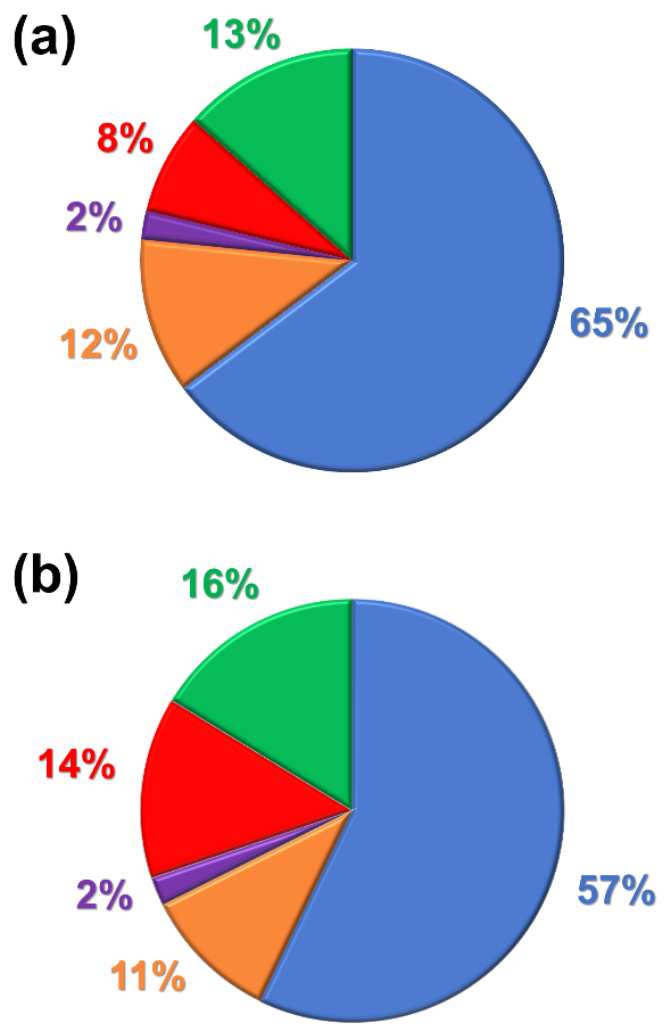

General population

Industrial sector

Retail trade

Food sector

Services

Figure 5. Pie charts showing the production rates of wastes from different sectors regarding masks in the whole year 2020 (a) and gloves in the period of phases 1 and 2 (b).

\subsection{Forecasting of the Future Periods}

Based on the data of waste production from used PPEs calculated for 2020 in the previous sections, a preliminary forecast of waste production rate and dispersions was performed. Three scenarios were set and are listed in Figure 6: The estimated percentages of dispersed PPEs were retrieved from data of general plastic waste [49], and the amount of plastic waste generated by PPEs was assumed based on the overall production of 2020, starting from the lockdown period in Lombardy (March 2020). The average weekly amount was calculated for the 2020 pandemic period (and considered as a medium impact scenario), and possible increases or decreases were considered (for the high impact and low impact scenarios, respectively) in order to forecast 2021 waste production.

While during 2021, a reduced amount of glove use is expected, especially by the general population, it is also expected that unrestricted mobility of the population (differently from the 1st phase of March 2020) is likely to happen. It should also be considered that the first vaccine distribution in Italy is likely to happen during 2021, but the use of PPEs by the general population will continue since PPE use is also suggested for vaccinated people in Italy [50]. Therefore, it is expectable that the overall amount of waste to be managed will be at least similar to the past year.

Moreover, considering a possible increase in PPE usage and mobility by the general population derived from less severe limitations on mobility (compared to 2020) and a plausible consequent increase in mismanagement rate of wastes, up to 30 tons of plastic waste might be directly dispersed in the environment every week during 2021 in the worst scenario (Figure 6).

However, some possible alternatives for the general population (e.g., washable masks and biodegradable PPEs, see Section 3.1) can possibly reduce the production of waste derived from PPEs in 2021, as forecasted in the low impact scenario (Figure 6). 


\section{(a)}

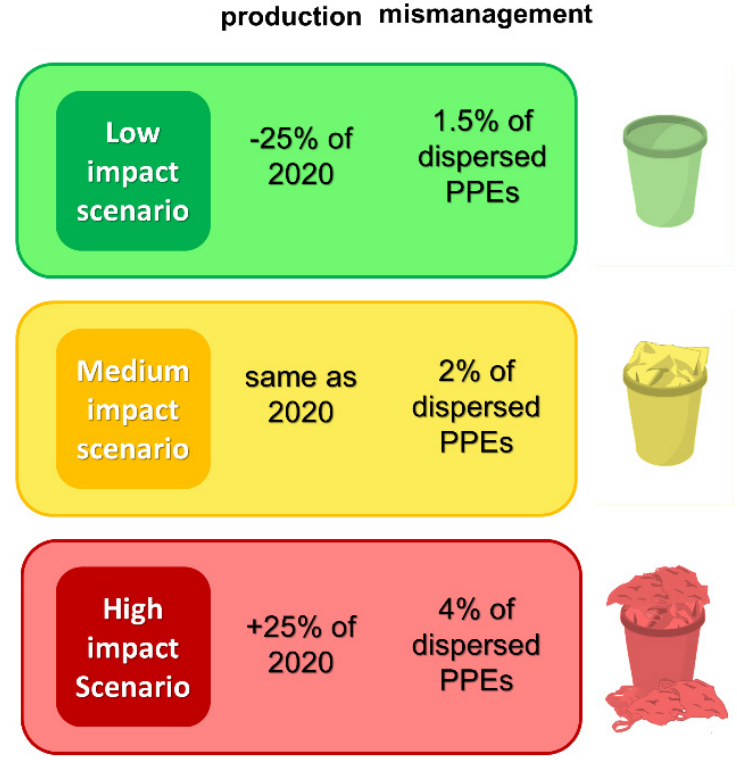

(b)

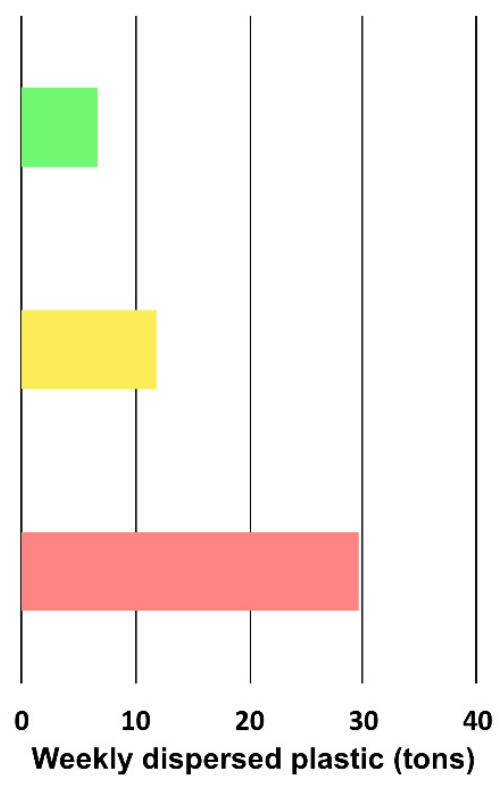

Figure 6. (a) Parameters used for the establishment of a future scenario (including an increasing, decreasing, or similar weekly amount of the 2020 average value and different rates of mismanaged waste [49]). (b) Estimated dispersed plastic waste from PPEs usage weekly in the different scenarios.

\section{Discussion}

Following the quantitative evaluation of used PPEs in 2020 and the forecast for 2021, the potential effects of their abundant increase, both on the waste management system and directly on the surrounding environment, will be critically evaluated in this section. Moreover, suggestions for the conscious use of PPEs (and careful management of the derived waste) will be proposed in order to reduce the environmental side effects derived from the COVID-19 pandemic.

\subsection{Impacts on the Waste Management System}

Considering the normal amount of plastic waste managed in Lombardy (up to 20,000 tons per month [51]), the period of the 2nd phase of lockdown in Lombardy caused an increase in plastic waste of about $25 \%$ derived from the use of PPEs. Therefore, while a general reduction in domestic waste was observed in Milan (the main city of Lombardy) during the phase 1 lockdown [52], an important increase in waste derived from PPEs happened during the whole of 2020. It should also be noted that this situation was foreseen by the competent authorities: On 1 April 2020, the president of the Lombardy region issued an order enshrining an increase in the storage capacities of waste treatment plants [53].

The procedures for managing waste derived from exhausted PPEs during COVID19 disease are clarified by the Istituto Superiore di Sanità (ISS) [35]. According to this guideline, PPEs should be disposed of with unsorted waste. Moreover, it was suggested to double-bag any potentially infective waste [15]. In this way, the reduction in the recycling of a material that in normal condition could be easily recycled [4] can cause complications in waste management, such as:

- Additional costs [54], quantified as almost 9 million euros for Lombardy in 2020, considering the overall amount of waste derived from the general population and the average price for a ton of general waste management in Lombardy (i.e., $291 € /$ ton [51]);

- An increase in carbon footprint and $\mathrm{CO}_{2}$ emissions [55];

- The possible environmental risks, such as the emissions of dioxins from the incineration of vinyl gloves [56]. 


\subsection{Impacts on the Environment: The Potential Effects of PPEs and Their Environmental Fate}

As for all plastic waste dispersed into the environment, rivers and lakes (abundant water bodies in the study area) and the sea are expected to be the main sinks of dispersed PPEs [57]. In fact, $80 \%$ of plastic litter is reported to be delivered to the ocean by land-based sources [58] and plastic pellets represent between $50 \%$ and $80 \%$ of the total waste occurring on beaches and in water and on seabeds [59]. The first reports of diffused PPEs in water bodies were recently presented in the literature [52]. While their accumulation in water bodies causes evident and serious issues for the environmental value of water bodies and their fauna, the possible weathering of dispersed PPEs can present even more concerning side effects.

Disposable PPEs used during the COVID-19 pandemic are mainly made of polymers, such as nitrile rubber, latex, or polyethylene, which require the use of additives, such as softeners, stabilizers, and flame retardants, to enhance their physical properties [60,61].

When PPEs are spread widely into the environment, these substances, which can be toxic or have endocrine disruptor features [62], undergo leaching processes (especially in the water environment), negatively affecting organisms [63,64]. Moreover, some of these polymers present known toxic effects on living organisms [65].

Another concerning side-effect of PPE weathering is the deterioration by UV radiations and physical abrasion of the polymers $[59,64,66,67]$, possibly generating microplastics (i.e., particles with size $<5 \mathrm{~mm}$; [24,68]). Microplastics can adsorb water pollutants and, due to their dimensions, could be ingested by water organisms, affecting the food chain, with potential bioaccumulation in humans, too [69-71].

In this view, the use of masks probably presents a more concerning environmental risk (Figure 7). In fact, while the glove degradation rate is comparable with other polymers, the fibrous material of face masks suggests a faster mechanical degradation into microfibers [72].

(a)

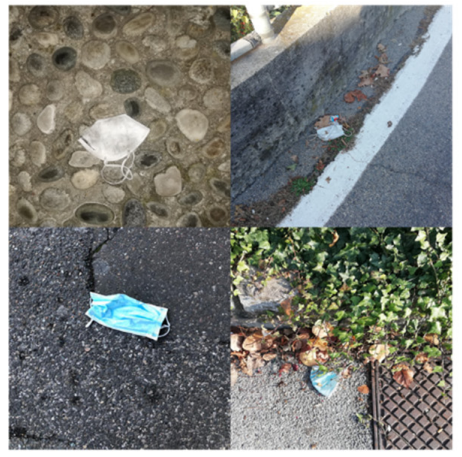

(b)

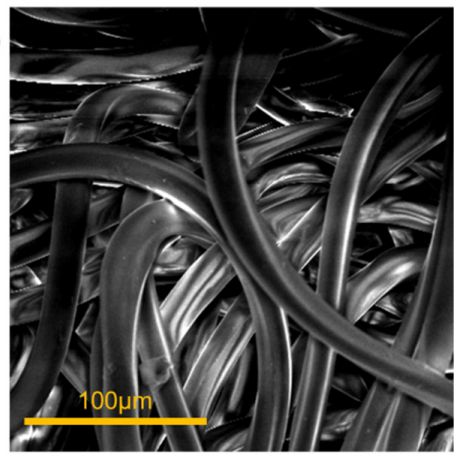

(c)

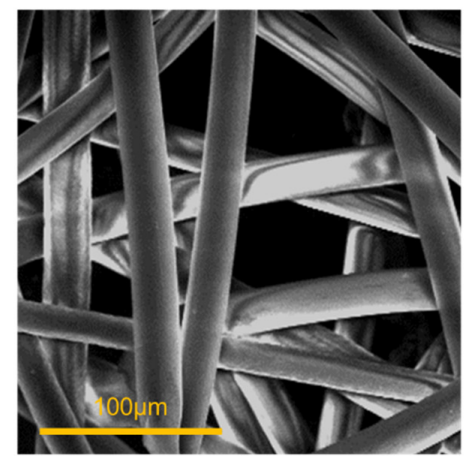

Figure 7. Photos of dispersed masks in Lombardy (a). Scanning Electron Microscope (SEM) micrographs of the elastic (b) and outer surface (c) of a surgical mask, showing the fibrous material as a possible source of microplastics. 


\subsection{Necessary Measures and Solutions for Minimizing the Impact}

The use of disposable PPEs was strongly recommended by the national government in Italy since clearly the main issue to solve was the spread of COVID-19 diffusion, and their secondary environmental impacts were scarcely considered.

Focusing on gloves, their use was limited after the 3rd phase of the pandemic in Italy since they require adequate preparation with the correct procedures in their utilization, and their incorrect use can cause adverse effects (e.g., self-contamination [73]). Consequently, the use of plastic gloves was maintained mostly for the more exposed categories of the population (i.e., health workers $[3,13])$. This change in general population habits significantly limited the effects of increased demand for gloves and possible consequent plastic pollution.

As an alternative, WHO recommended alcohol-based hand sanitizers for frequent hand hygiene. Nonetheless, while these measures can work perfectly in the short-term, long-term effects should be considered in future studies. These products are mainly made from ethanol, isopropyl alcohols, hydrogen peroxides in different combinations, which can have some negative side effects (e.g., irritation and allergic condition of skin and eyes by dermal contact $[74,75])$. However, their use for hand hygiene results in a more sustainable way to avoid contagion compared to gloves.

Moving to masks, these PPEs are known reliable tools for reducing COVID-19 spread (as for other contagious diseases). Their effect in the fight in the COVID-19 pandemic has already been highlighted, and their substitution is not considered yet [48]. The only reliable and more sustainable measure to apply under present conditions is the use of washable and reusable masks, at least for the general population and low-risk environments (e.g., shops and open spaces). These masks, if prepared with adequate textiles, can perform similar filtration efficiency [76,77], representing a greener alternative in terms of plastic pollution and also in terms of $\mathrm{CO}_{2}$ emission related to the mask lifetime [55]. Nonetheless, the filtration efficiency has to be better tested after more washing cycles to understand how washing can affect performances. As well, future studies should also focus on the issue of plastic microfiber pollution related to reusable masks and their washing, as for other synthetic textiles [77].

Another recently proposed alternatives include the use of biodegradable polymers as the basis for the production of face masks [78]. This alternative should be considered, especially for future scenarios of possible new pandemics.

As observed from Figure 5, the general population have an important effect on the plastic waste production derived from the use of PPEs, and the sustainable use of these protections can actively reduce the plastic pollution related to the COVID-19 outbreak. Moreover, to trace and monitor the potential effects of PPEs-related plastic pollution, a key role in monitoring the impact could be played by water management societies (e.g., environmental protection agencies and water suppliers) and wastewater treatment plants. In fact, besides playing an important role in evaluating SARS-Cov II persistence in water [79-81], these services can monitor and evaluate the risk posed by this emerging and recent source of plastic pollution and plan strategies for remediation systems.

\section{Conclusions}

In summary, this work highlighted the role of the general population in the PPEsderived waste generation after the COVID-19 pandemic, analyzing the data of the Lombardy region in Italy, an area that was among the first struck by COVID-19 diffusion. The evaluation of the impacts in 2020 and the forecast for 2021 highlighted an important increase in plastic waste derived from used PPEs, confirming an important role of the general population in the environmental issue of PPEs-derived waste.

This increase in plastic waste directly affects (especially in term of costs) the waste management system, but more importantly, can increase the environmental impacts derived from plastic pollution. PPEs can be, in fact, a source of microplastic particles if directly dispersed into the environment (this is especially true for face masks). 
Additionally, the estimated increment in the amount of waste by our case study highlights the potential threats which probably also affect other urban contexts, especially in developing countries that can have problems in waste management. This is an issue that needs to be faced in future scenarios of the COVID-19 pandemic.

Considering the potential environmental threats of PPEs-derived waste, conscious use of PPEs (especially by the general population) and careful waste management play an important role in avoiding the spread of COVID-19 and also reducing environmental impact. Other forms of preventions (i.e., sanitizers, social distancing, reusable masks) could successfully represent environmentally friendly alternatives to single-use PPEs. Considering the ongoing diffusion of COVID-19, the conscious use of PPEs by the general population is of great importance to avoid the severe negative environmental implications of this pandemic.

Supplementary Materials: The following are available online at https:/ /www.mdpi.com/article/10 .3390 /environments8040033/s1, Table S1: People in Lombardy for the different population classes analyzed in our study, and source of the data obtained; Table S2: Total numbers of masks wasted weekly (in tons) for different classes of the population during the different phases of lockdown established in Lombardy; Table S3: Total number of gloves wasted weekly (in tons) for different classes of the population during the different phases of lockdown established in Lombardy.

Author Contributions: G.B.: Data curation; Writing—original draft. A.B.: Writing—original draft; Data curation. D.S.: Data curation; Writing-Review \& Editing. A.P.: Supervision, Writing—Review \& Editing. D.C.: Supervision, Writing—Review \& Editing. R.B.: Conceptualization, Supervision, Writing—Review \& Editing. All authors have read and agreed to the published version of the manuscript.

Funding: This research received no external funding.

Data Availability Statement: Publicly available datasets were analyzed in this study. Sources of data can be found in Supplementary Materials, Table S1.

Acknowledgments: The authors wish to thank the two anonymous reviewers for their helpful comments, which improved manuscript quality.

Conflicts of Interest: The authors declare no conflict of interest.

\section{References}

1. Xu, Z.; Shi, L.; Wang, Y.; Zhang, J.; Huang, L.; Zhang, C.; Liu, S.; Zhao, P.; Liu, H.; Zhu, L.; et al. Pathological findings of COVID-19 associated with acute respiratory distress syndrome. Lancet Respir. Med. 2020, 8, 420-422. [CrossRef]

2. Sohrabi, C.; Alsafi, Z.; O’Neill, N.; Khan, M.; Kerwan, A.; Al-Jabir, A.; Iosifidis, C.; Agha, R. World Health Organization de-clares global emergency: A review of the 2019 novel coronavirus (COVID-19). Int. J. Surg. 2020, 76, 71-76. [CrossRef]

3. Spinazzè, A.; Cattaneo, A.; Cavallo, D.M. COVID-19 Outbreak in Italy: Protecting Worker Health and the Response of the Italian Industrial Hygienists Association. Ann. Work. Expo. Health 2020, 64, 559-564. [CrossRef]

4. Zambrano-Monserrate, M.A.; Ruano, M.A.; Sanchez-Alcalde, L. Indirect effects of COVID-19 on the environment. Sci. Total Environ. 2020, 728, 138813. [CrossRef] [PubMed]

5. Saadat, S.; Rawtani, D.; Hussain, C.M. Environmental perspective of COVID-19. Sci. Total Environ. 2020, 728, 138870. [CrossRef]

6. Gautam, S.; Hens, L. COVID-19: Impact by and on the environment, health and economy. Environ. Dev. Sustain. 2020, 22, 4953-4954. [CrossRef]

7. Venter, Z.S.; Aunan, K.; Chowdhury, S.; Lelieveld, J. COVID-19 lockdowns cause global air pollution declines with implica-tions for public health risk. medRxiv 2020, 7162. [CrossRef]

8. Sharma, S.; Zhang, M.; Gao, J.; Zhang, H.; Kota, S.H. Effect of restricted emissions during COVID-19 on air quality in India. Sci. Total Environ. 2020, 728, 138878. [CrossRef] [PubMed]

9. Collivignarelli, M.C.; Abbà, A.; Bertanza, G.; Pedrazzani, R.; Ricciardi, P.; Carnevale Miino, M. Lockdown for CoViD-2019 in Milan: What are the effects on air quality? Sci. Total Environ. 2020, 732, 139280. [CrossRef] [PubMed]

10. Bar, H. COVID-19 lockdown: Animal life, ecosystem and atmospheric environment. Environ. Dev. Sustain. 2020, 1-18. [CrossRef]

11. Sarkar, M.; Das, A.; Mukhopadhyay, S. Assessing the immediate impact of COVID-19 lockdown on the air quality of Kolkata and Howrah, West Bengal, India. Environ. Dev. Sustain. 2020, 1-30. [CrossRef] [PubMed]

12. Yunus, A.P.; Masago, Y.; Hijioka, Y. COVID-19 and surface water quality: Improved lake water quality during the lock-down. Sci. Total Environ. 2020, 731, 139012. [CrossRef] [PubMed] 
13. Rowan, N.J.; Laffey, J.G. Challenges and solutions for addressing critical shortage of supply chain for personal and protective equipment (PPE) arising from Coronavirus disease (COVID19) pandemic-Case study from the Republic of Ireland. Sci. Total Environ. 2020, 725, 138532. [CrossRef]

14. Park, C.-Y.; Kim, K.; Roth, S.; Beck, S.; Kang, J.W.; Tayag, M.C.; Grifin, M.; Asian Development Bank; World Health Organization. Global Shortage of Personal Protective Equipment amid COVID-19: Supply Chains, Bottlenecks, and Policy Implications. ADB Briefs 2020, 108, 1-8. [CrossRef]

15. Klemeš, J.J.; Van Fan, Y.; Tan, R.R.; Jiang, P. Minimising the present and future plastic waste, energy and environmental footprints related to COVID-19. Renew. Sustain. Energy Rev. 2020, 127, 109883. [CrossRef]

16. Yu, H.; Sun, X.; Solvang, W.D.; Zhao, X. Reverse logistics network design for effective management of medical waste in epi-demic outbreaks: Insights from the coronavirus disease 2019 (COVID-19) outbreak in Wuhan (China). Int. J. Environ. Res. Public Health 2020, 17, 1770. [CrossRef] [PubMed]

17. Patrício Silva, A.L.; Prata, J.C.; Walker, T.R.; Duarte, A.C.; Ouyang, W.; Barcelò, D.; Rocha-Santos, T. Increased plastic pollu-tion due to COVID-19 pandemic: Challenges and recommendations. Chem. Eng. J. 2021, 405, 126683. [CrossRef]

18. Prata, J.C.; Silva, A.L.P.; Walker, T.R.; Duarte, A.C.; Rocha-Santos, T. COVID-19 Pandemic Repercussions on the Use and Management of Plastics. Environ. Sci. Technol. 2020, 54, 7760-7765. [CrossRef] [PubMed]

19. Adyel, T.M. Accumulation of plastic waste during COVID-19. Science 2020, 369, 1314-1315. [CrossRef] [PubMed]

20. Fadare, O.O.; Okoffo, E.D. Covid-19 face masks: A potential source of microplastic fibers in the environment. Sci. Total Environ. 2020, 737, 140279. [CrossRef]

21. Lambert, S.; Sinclair, C.J.; Bradley, E.L.; Boxall, A.B.A. Environmental fate of processed natural rubber latex. Environ. Sci. Process. Impacts 2013, 15, 1359-1368. [CrossRef]

22. Briassoulis, D.; Aristopoulou, A.; Bonora, M.; Verlodt, I. Degradation Characterisation of Agricultural Low-density Polyeth-ylene Films. Biosyst. Eng. 2004, 88, 131-143. [CrossRef]

23. Sen, S.K.; Raut, S. Microbial degradation of low density polyethylene (LDPE): A review. J. Environ. Chem. Eng. 2015, 3, 462-473. [CrossRef]

24. Bellasi, A.; Binda, G.; Pozzi, A.; Galafassi, S.; Volta, P.; Bettinetti, R. Microplastic Contamination in Freshwater Environments: A Review, Focusing on Interactions with Sediments and Benthic Organisms. Environments 2020, 7, 30. [CrossRef]

25. Consiglio dei Ministri Decreto del Presidente del Consiglio dei Ministri 26 Aprile 2020. Available online: http:/ / www.governo. it/sites/new.governo.it/files/Dpcm_img_20200426.pdf (accessed on 28 April 2020).

26. Kumar, H.; Azad, A.; Gupta, A.; Sharma, J.; Bherwani, H.; Labhsetwar, N.K.; Kumar, R. COVID-19 Creating another prob-lem? Sustainable solution for PPE disposal through LCA approach. Environ. Dev. Sustain. 2020, 1-15. [CrossRef]

27. Remuzzi, A.; Remuzzi, G. COVID-19 and Italy: What next? Lancet 2020, 395, 1225-1228. [CrossRef]

28. Paterlini, M. On the front lines of coronavirus: The Italian response to covid-19. BMJ 2020, 368, m1065. [CrossRef] [PubMed]

29. Grasselli, G.; Zangrillo, A.; Zanella, A.; Antonelli, M.; Cabrini, L.; Castelli, A.; Cereda, D.; Coluccello, A.; Foti, G.; Fumagalli, R.; et al. Baseline Characteristics and Outcomes of 1591 Patients Infected With SARS-CoV-2 Admitted to ICUs of the Lom-bardy Region, Italy. JAMA 2020, 323, 1574. [CrossRef] [PubMed]

30. Spina, S.; Marrazzo, F.; Migliari, M.; Stucchi, R.; Sforza, A.; Fumagalli, R. The response of Milan's Emergency Medical System to the COVID-19 outbreak in Italy. Lancet 2020, 395, e49-e50. [CrossRef]

31. Armocida, B.; Formenti, B.; Ussai, S.; Palestra, F.; Missoni, E. The Italian health system and the COVID-19 challenge. Lancet Public Health 2020, 5, e253. [CrossRef]

32. ISTAT Istituto Nazionale di Statistica. Available online: https:/ / www.istat.it/ (accessed on 30 April 2020).

33. Lab24 Coronavirus. Available online: https:/ /lab24.ilsole24ore.com/coronavirus/ (accessed on 15 January 2021).

34. Huang, Z.; Huang, J.; Gu, Q.; Du, P.; Liang, H.; Dong, Q. Optimal temperature zone for the dispersal of COVID-19. Sci. Total Environ. 2020, 736, 139487. [CrossRef]

35. ISS Indicazioni ad Interim per la Gestione dei Rifiuti Urbani in Relazione Alla Trasmissione Dell'infezione da Virus SARS-COV-2. Available online: https:/ / www.iss.it/altre-pubblicazioni/-_asset_publisher/btw1J82wtYzH/content/id/5299930 (accessed on 12 May 2020).

36. Ministero del Lavoro e Delle Politiche Sociali Protocollo Condiviso di Regolamentazione Delle Misure per il Contrasto e il Con-tenimento Della Diffusione del Virus Covid-19 Negli Ambienti di Lavoro. Available online: https:/ / www.lavoro.gov.it/ notizie/Documents/Protocollo-24-aprile-2020-condiviso-misure-di-contrasto\%20Covid-19.pdf (accessed on 2 May 2020).

37. Regione Lombardia Portale Istituzionale. Available online: https://www.regione.lombardia.it/wps/portal/istituzionale/ (accessed on 3 May 2020).

38. Unioncamere Lombardia Camere di Commercio Lombarde. Available online: http://www.unioncamerelombardia.it/?/home (accessed on 6 May 2020).

39. Coldiretti Coldiretti. Available online: https://www.coldiretti.it/ (accessed on 4 May 2020).

40. Confcommercio Ristorazione-Rapporto Annuale. 2019. Available online: https://www.confcommercio.it/documents/20126/0/ Rapporto+Ristorazione+2019+Fipe.pdf/27de185c-4d5d-9e60-abc4-7248d254846e?version=1.0\&t=1579623545575 (accessed on 16 May 2020).

41. ISFORT Rapporto Sulla Mobilità Degli Italiani “Audimob". Available online: https://www.isfort.it/progetti/17-rapportoaudimob-sulla-mobilita-degli-italiani/ (accessed on 15 May 2020). 
42. AGI Coronavirus e Lockdown, il Pesante Conto per le Imprese. Available online: https://www.agi.it/economia/news/2020-0615/coronavirus-imprese-lockdown-istat-8903854/ (accessed on 9 December 2020).

43. ISS Raccomandazioni ad Interim sui Disinfettanti Nell'attuale Emergenza COVID-19: Presidi Medico Chirurgici e Biocidi. Available online: https://www.epicentro.iss.it/coronavirus/pdf/rapporto-covid-19-19-2020.pdf (accessed on 30 April 2020).

44. INAIL Documento Tecnico su Ipotesi di Rimodulazione Delle Misure Contenitive del Contagio da SARS-CoV-2 nel Settore Della Ristorazione. Available online: https:/ / anci.lombardia.it/documenti/9964-Documento\%20tecnico\%20ristorazione.pdf (accessed on 10 June 2020).

45. Ministero del Lavoro e Delle Politiche Sociali Nota Trimestrale Sulle Tendenze Dell'occupazione. Available online: https:/ www. lavoro.gov.it/notizie/Pagine/Nota-trimestrale-sulle-tendenze-dell-occupazione-II-trimestre-2020.aspx\#: :text=IItrimestre202 $0-, \backslash \mathrm{T} 1 \backslash$ textquotedblleftNotatrimestralesulletendenzedell $\backslash \mathrm{T} 1 \backslash$ textquoterightoccupazione $\backslash \mathrm{T} 1 \backslash$ textquotedblright $\% 3 A$ èonline, rilevazionedelIItrimestre2020\&text=L \T1 \textquoterightandamentod (accessed on 27 November 2020).

46. Van Fan, Y.; Jiang, P.; Hemzal, M.; Klemeš, J.J. An update of COVID-19 influence on waste management. Sci. Total Environ. 2021, 754, 142014. [CrossRef]

47. Bericah, S.P.A. Guanti Monouso. Available online: www.cleaner.it/wp-content/uploads/2018/06/catalogo_-guanti_monouso. pdf (accessed on 5 May 2020).

48. Chua, M.H.; Cheng, W.; Goh, S.S.; Kong, J.; Li, B.; Lim, J.Y.C.; Mao, L.; Wang, S.; Xue, K.; Yang, L.; et al. Face Masks in the New COVID-19 Normal: Materials, Testing, and Perspectives. Research 2020, 2020, 1-40. [CrossRef] [PubMed]

49. Penca, J. European Plastics Strategy: What promise for global marine litter? Mar. Policy 2018, 97, 197-201. [CrossRef]

50. Bonanni, P.; Angelillo, I.; Villani, A.; Biasci, P.; Scotti, S.; Russo, R.; Maio, T.; Rosati, G.V.; Barretta, M.; Bozzola, E.; et al. Maintain and increase vaccination coverage in children, adolescents, adults and elderly people: Let's avoid adding epidemics to the pandemic. Vaccine 2021, 39, 1187-1189. [CrossRef]

51. ISPRA Rapporto Rifiuti Urbani. 2019. Available online: http://www.isprambiente.gov.it/it/pubblicazioni/rapporti/rapportorifiuti-urbani-edizione-2019 (accessed on 8 May 2020).

52. Sarkodie, S.A.; Owusu, P.A. Impact of COVID-19 pandemic on waste management. Environ. Dev. Sustain. 2020, 1-10. [CrossRef] [PubMed]

53. Regione Lombardia Ordinanza Contingibile ed Urgente ai Sensi Dell'art. 191 del D.Lgs 152/2006. Disposizioni Urgenti in Mate-ria di Gestione dei Rifiuti e di Bonifica a Seguito Dell'emergenza Epidemiologica da COVID-19. Available online: https:/ / www.regione.lombardia.it/wps/wcm/connect/5a9fbfe2-f47e-4026-88b2-6f4b65f27f16/Ordinanza_520_01-04-2020.pdf? MOD=AJPERES\&CACHEID=ROOTWORKSPACE-5a9fbfe2-f47e-4026-88b2-6f4b65f27f16-n4X8Jwp (accessed on 12 May 2020).

54. Sözer, H.; Sözen, H. Waste capacity and its environmental impact of a residential district during its life cycle. Energy Rep. 2020, 6, 286-296. [CrossRef]

55. Klemeš, J.J.; Van Fan, Y.; Jiang, P. The energy and environmental footprints of COVID-19 fighting measures-PPE, disinfec-tion, supply chains. Energy 2020, 211, 118701. [CrossRef] [PubMed]

56. Buekens, A.; Cen, K. Waste incineration, PVC, and dioxins. J. Mater. Cycles Waste Manag. 2011, 13, 190-197. [CrossRef]

57. Bellasi, A.; Binda, G.; Pozzi, A.; Boldrocchi, G.; Bettinetti, R. The extraction of microplastics from sediments: An overview of existing methods and the proposal of a new and green alternative. Chemosphere 2021, 130357. [CrossRef]

58. Andrady, A.L.; Neal, M.A. Applications and societal benefits of plastics. Philos. Trans. R. Soc. B Biol. Sci. 2009, 364, 1977-1984. [CrossRef]

59. Barnes, D.K.A.; Galgani, F.; Thompson, R.C.; Barlaz, M. Accumulation and fragmentation of plastic debris in global envi-ronments. Philos. Trans. R. Soc. B Biol. Sci. 2009, 364, 1985-1998. [CrossRef] [PubMed]

60. Conde-Salazar, L.; Del-Río, E.; Guimaraens, D.; Domingo, A.G. Type IV allergy to rubber additives: A 10 -year study of 686 cases. J. Am. Acad. Dermatol. 1993, 29, 176-180. [CrossRef]

61. Mutsuga, M.; Wakui, C.; Kawamura, Y.; Maitani, T. Isolation and identification of some unknown substances in disposable nitrile-butadiene rubber gloves used for food handling. Food Addit. Contam. 2002, 19, 1097-1103. [CrossRef] [PubMed]

62. Lithner, D.; Damberg, J.; Dave, G.; Larsson, Å. Leachates from plastic consumer products-Screening for toxicity with Daphnia magna. Chemosphere 2009, 74, 1195-1200. [CrossRef] [PubMed]

63. Endo, S.; Yuyama, M.; Takada, H. Desorption kinetics of hydrophobic organic contaminants from marine plastic pellets. Mar. Pollut. Bull. 2013, 74, 125-131. [CrossRef] [PubMed]

64. Liu, J.; Li, X.; Xu, L.; Zhang, P. Investigation of aging behavior and mechanism of nitrile-butadiene rubber (NBR) in the ac-celerated thermal aging environment. Polym. Test. 2016, 54, 59-66. [CrossRef]

65. Bogdanffy, M.S.; Sarangapani, R.; Plowchalk, D.R.; Jarabek, A.; Andersen, M.E. A biologically based risk assessment for vinyl acetate-induced cancer and noncancer inhalation toxicity. Toxicol. Sci. 1999, 51, 19-35. [CrossRef] [PubMed]

66. Lambert, S.; Sinclair, C.; Boxall, A. Occurrence, degradation, and effect of polymer-based materials in the environment. Rev. Environ. Contam. Toxicol. 2014, 227, 1-53. [PubMed]

67. Radhakrishnan, C.; Alex, R.; Unnikrishnan, G. Thermal, ozone and gamma ageing of styrene butadiene rubber and poly(ethyleneco-vinyl acetate) blends. Polym. Degrad. Stab. 2006, 91, 902-910. [CrossRef]

68. Peng, G.; Xu, P.; Zhu, B.; Bai, M.; Li, D. Microplastics in freshwater river sediments in Shanghai, China: A case study of risk assessment in mega-cities. Environ. Pollut. 2018, 234, 448-456. [CrossRef] 
69. Akhbarizadeh, R.; Moore, F.; Keshavarzi, B. Investigating microplastics bioaccumulation and biomagnification in seafood from the Persian Gulf: A threat to human health? Food Addit. Contam.-Part A Chem. Anal. Control Expo. Risk Assess 2019, 36, 1696-1708. [CrossRef]

70. Eerkes-Medrano, D.; Thompson, R.C.; Aldridge, D.C. Microplastics in freshwater systems: A review of the emerging threats, identification of knowledge gaps and prioritisation of research needs. Water Res. 2015, 75, 63-82. [CrossRef] [PubMed]

71. Carbery, M.; O'Connor, W.; Palanisami, T. Trophic transfer of microplastics and mixed contaminants in the marine food web and implications for human health. Environ. Int. 2018, 115, 400-409. [CrossRef] [PubMed]

72. Aragaw, T.A. Surgical face masks as a potential source for microplastic pollution in the COVID-19 scenario. Mar. Pollut. Bull. 2020, 159, 111517. [CrossRef] [PubMed]

73. Doll, M.; Feldman, M.; Hartigan, S.; Sanogo, K.; Stevens, M.; McReynolds, M.; Masroor, N.; Cooper, K.; Bearman, G. Ac-ceptability and Necessity of Training for Optimal Personal Protective Equipment Use. Infect. Control Hosp. Epidemiol. 2017, 38, 226-229. [CrossRef] [PubMed]

74. Li, D.; Sangion, A.; Li, L. Evaluating consumer exposure to disinfecting chemicals against coronavirus disease 2019 (COVID-19) and associated health risks. Environ. Int. 2020, 145, 106108. [CrossRef]

75. Mahmood, A.; Eqan, M.; Pervez, S.; Alghamdi, H.A.; Tabinda, A.B.; Yasar, A.; Brindhadevi, K.; Pugazhendhi, A. COVID-19 and frequent use of hand sanitizers; human health and environmental hazards by exposure pathways. Sci. Total Environ. 2020, 742, 140561. [CrossRef] [PubMed]

76. Lee, K.-P.; Yip, J.; Kan, C.-W.; Chiou, J.-C.; Yung, K.-F. Reusable Face Masks as Alternative for Disposable Medical Masks: Factors that Affect their Wear-Comfort. Int. J. Environ. Res. Public Health 2020, 17, 6623. [CrossRef]

77. Shruti, V.; Pérez-Guevara, F.; Elizalde-Martínez, I.; Kutralam-Muniasamy, G. Reusable masks for COVID-19: A missing piece of the microplastic problem during the global health crisis. Mar. Pollut. Bull. 2020, 161, 111777. [CrossRef]

78. Das, O.; Neisiany, R.E.; Capezza, A.J.; Hedenqvist, M.S.; Försth, M.; Xu, Q.; Jiang, L.; Ji, D.; Ramakrishna, S. The need for fully bio-based facemasks to counter coronavirus outbreaks: A perspective. Sci. Total Environ. 2020, 736, 139611. [CrossRef] [PubMed]

79. Annalaura, C.; Federigi, I.; Dasheng, L.; Julian, R.T.; Marco, V. Making waves: Coronavirus detection, presence and persis-tence in the water environment: State of the art and knowledge needs for public health. Water Res. 2020, 179, 115907.

80. Ahmed, W.; Angel, N.; Edson, J.; Bibby, K.; Bivins, A.; O’Brien, J.W.; Choi, P.M.; Kitajima, M.; Simpson, S.L.; Li, J.; et al. First confirmed detection of SARS-CoV-2 in untreated wastewater in Australia: A proof of concept for the wastewater surveil-lance of COVID-19 in the community. Sci. Total Environ. 2020, 728, 138764. [CrossRef] [PubMed]

81. Rimoldi, S.G.; Stefani, F.; Gigantiello, A.; Polesello, S.; Comandatore, F.; Mileto, D.; Maresca, M.; Longobardi, C.; Mancon, A.; Romeri, F.; et al. Presence and infectivity of SARS-CoV-2 virus in wastewaters and rivers. Sci. Total Environ. 2020, 744, 140911. [CrossRef] [PubMed] 